on this and other sero-diagnostic techniques for cancer, we have isolated specimens of the mucoprotein from human serum, using both the sulphosalicylic and perchloric acid methods of isolation. The nitrogen and tyrosine contents were, respectively, 7.09 and 3.05 gm. per cent dried material, which are close to those given by Winzler et $a l .^{3}$.

By chromatographic analysis of hydrolysates on filter paper, we have distinguished the following amino-acid components : phenylalanine, leucine and isoleucine, tyrosine, methionine, valine, proline, alanine, threonine, serine, glycine, aspartic acid, glutamic acid, histidine, lysine and arginine. Cyst(e)ine has been identified polarographically on the unhydrolysed material, while tryptophane and tyrosine have been distinguished by a study of the ultra-violet absorption curve. The qualitative analysis for all these amino-acids has not previously been reported, although Winzler gave the following values : cystine $0 \cdot 5$, tyrosine $4 \cdot 2$, methionine $2 \cdot 1$, tryptophane $1.8 \mathrm{gm}$. per cent dry weight.

The sugar components of ox sero-mucoid have been reported by Werner and Odin ${ }^{5}$ as mannose, galactose and glucosamine. Using a similar pyridine/amyl alcohol/water mixture as solvent, we have separated and identified in the human sero-mucoid these same constituents.

After developing the colour for the amino-sugars with the Morgan and Elson reagent?, a spot produced by a reactant with slew mobility was observed. We believe this may be attributed to a compound formed by the interaction of hexoses with lysine or other amino-acids which has been described by Horowitz et al. . $^{2}$.

Work on the quantitative analysis of human seromucoprotein derived from human normal and cancer serum is proceeding for the amino-acid and sugar components.

Cancer Research Laboratories,

DEIRDRE M. WALDRON

D. L. WOODHOUSE

Department of Pathology,

Medical School,

University, Birmingham, 15. April 1

2 Rimington, C., Biochem. J., 34, 931 (1940). Rimington, C., and Staub, A. M., Biochem. J., 42, 5 (1948).

${ }^{3}$ Hewitt, L. F., Biochem. J., 31, 1534 (1937) ; 33, 1497 (1939).

Winzler, R. J., Devor, A. W., MehI, J. W., and Smyth, I., J. Clin. Invest., 27,617 (1948).

4 Mehl, J. W., Humphrey, J., and Winzler, R. J., Proc. Soc. Exp. Biol., 72, $106(1949)$. Mehi, J. W., Golden, F., and Winzler, R J., Proc. Soc. Exp. Biol., 72,110 (1949).

Werner, I., and Odin L., Upsala Läkarefören. Förhandl., N.T., 54, Häft 1-2, 69 (1949).

- Brdicka, R., Acta. Radiol. ef Canerol. Bohemiae et Moraviae, 2, 7 1930 .

7 Murgan, W. T. S., and Elson, L. A., Biochem. $J$, 28, 988 (1934).

- Horowitz, N. H., Ikawa, M., and Fling, M., Areh. Biochem., 25, 1, 226 (1950)

\section{A Sulphated Mucopolysaccharide in Human Dentine}

THE presence of a polysaccharide resembling chondroitin sulphate in human dentine has already been described ${ }^{1}$. An undegraded polysaccharide with a low ash content has now been separated from human dentine. Dry human dentine (1 gm.) is reduced to a 180/200 mesh powder, then dialysed in 1 litre of $0.05 N$ hydrochloric acid for about ten days with frequent changes, at room temperature; this reduces the calcium content. When the outer fluid shows only 3 trace of calcium, $p \mathrm{H}$ of the suspension is brought to 6.0 and it is then heated to $80^{\circ}$ for 20 min., as suggested by Partridge for cartilage ${ }^{2}$. The mass is then shaken with 10 per cent calcium chloride ${ }^{3}$ and again dialysed against distilled water. The bulk is then made up to about two litres with distilled water, and $p \mathrm{H}$ adjusted again to $6 \cdot 0$. Separation of protein is effected by shaking with $80 \mathrm{ml}$. chloroform and $32 \mathrm{ml}$. amyl alcohol to each litre. The bulk is then reduced by boiling at about $42^{\circ}$ under reduced pressure; drying is completed over phosphorus pentoxide. The yield from $1 \mathrm{gm}$. dry dentine was $26 \cdot 4 \mathrm{mgm}$. polysaccharide.

The polysaccharide has been hydrolysed : $(a)$ by a dried preparation of a Gram-negative bacillus isolated from dental caries; $(b)$ by a living culture of Penicillium spinulosum at room temperature (kindly identified by Mr. G. Smith, of the London School of Hygiene); (c) by $2 N$ hydrochloric acid in $10 \mathrm{hr}$. at $100^{\circ}$. Before hydrolysis neither free sulphate nor hexosamine can be detected, but both are found after hydrolysis by any of these three agents. Difficulty was met both in lowering the ash content and in separating polysaccharide from protein without degrading the polysaccharide. Meyer et al.4 describe a method of preparation of chondroitin sulphate from cartilage in which shaking with a chloroform-amyl alcohol mixture is repeated twenty-four times. In the present work, despite prolonged and repeated shakings, all polysaccharide separated from dentine gave a trace of colour when tested by the Sakaguchi reaction.

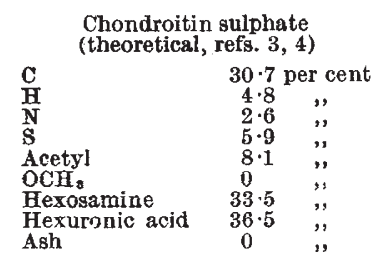

\begin{tabular}{|c|c|}
\hline $\begin{array}{l}\text { Found } \\
\text { mucons } \\
\text { from h }\end{array}$ & $\begin{array}{l}\text { sulph } \\
\text { accha } \\
\text { in der }\end{array}$ \\
\hline $42 \cdot 0$ & I cent \\
\hline & ", \\
\hline & $"$ \\
\hline $\begin{array}{l}4 \cdot 6 \\
8 \cdot 1\end{array}$ & $"$ \\
\hline 0 & $"$ \\
\hline 26. & ", \\
\hline $28 \cdot 0$ & $"$ \\
\hline
\end{tabular}

I am indebted to the Medical Research Council for financial assistance, and to my colleagues at this Hospital.

Department of Physiology,

P. Pincts

Middlesex Hospital Medical School, London, W.I.

March 30.

1 Pincus, P., Nature, 162, 1014 (1948)

a Partridge, S, M., Biochem. J., 43, 387 (1948)

'Meyer, K., and Smyth, E. M., J. Biol. Chem., 119, 507 (1937).

Meyer, K. H., Odier, M. E., and Sigrist, A. E., Helv. Chim. Acta, 31, $3400(1948)$.

\section{Inorganic Pyrophosphate in Insect Tissue}

As reported earlier by Heller ${ }^{1}$, the fat bodies of the male of the butterflies Deilephila euphorbia contain a substantial quantity, some $110 \mathrm{mgm}$. per cent, of phosphorus which yields inorganic orthophosphate on 7 minutes hydrolysis in $N$ hydrochloric acid at $100^{\circ} \mathrm{C}$. This readily hydrolysable phosphorus fraction, at first thought to consist chiefly of adenosinetriphosphate, was recently subjected by us to purification by the method of Jones ${ }^{2}$ (as modified by Lehninger and $S{ }^{2} i_{h}{ }^{3}$, which consists in precipitation of inorganic pyrophosphate as manganese salt but leaves adenosinetriphosphate in solution. 